\title{
SHAREHOLDER ACTIVISM: TELECOMMUNICATION INDUSTRY IN TURKEY
}

\author{
Emre ERGIN* \\ İlkay Ejder ERTURAN**
}

\begin{abstract}
Shareholders began to play an active role in diminishing the growing agency costs due to recent financial crisis, poor corporate governance and excessive executive compensations. They act as individual and corporate forms in order to protect their investment and increase firm value. Nowadays, social activities of the past have changed to replace the general manager, overcome the duality problem, elect a board member other than the management candidates, vote for acquisition or sale decisions, and dividend distribution. The ownership structure in Turkey is generally composed of families or individuals who do not act aggressively as the hedge funds in USA. The sales of Turkish companies' shares to foreign shareholders, introduction of international investment funds in the local market, and electronic general meeting system introduced a few years ago contribute to shareholder activism in Turkey. Shareholder struggles are witnessed only in the Turkish stock market which is quoted in the NYSE. In this study, the two publicly traded companies in the telecommunication sector, namely Türk Telekom and Turkcell, are examined in terms of their financial situation, the acceptance rate of the propositions of the management in the general meetings, and the behavior of their share prices. Shareholder activism is not seen in the Telekom, whereas there have been trials and regulation changes for Turkcell. In terms of accounting-based data, Türk Telekom has a lower operational profitability and current ratio as compared to Turkcell. It is concluded that the level of shareholder activism occurred in the general meetings does not affect the share prices. Both companies' shares moved in high correlation during the last three years. The share prices did not show abnormal patterns during the days following the general meetings. The reasons might be the growth of the telecommunication industry being above the national growth rate and the positive evaluations of the shareholders' decisions by the investors for the future of the firm.
\end{abstract}

Keywords: Shareholder Activism, Agency Theory, Telecommunication, Turkey

JEL Classification: G34, M12, M14

\footnotetext{
* Associate Prof., Kocaeli University, İzmit Vocational School, Accounting And Tax Department, emre.ergin@kocaeli.edu.tr

** Assistant Prof., Niğde University, Çilimli Vocational School, Accounting and Tax Department, ilkayerturan@duzce.edu.tr
} 


\title{
HISSEDAR AKTIVIZMI: TÜRKIYE TELEKOMÜNIKASYON SEKTÖRÜ
}

\begin{abstract}
Özet
Yaşanan finansal krizler, kötü kurumsal yönetişim ve aşırı üst yönetici ücretleri gibi nedenlerden dolayı artan temsil maliyetlerinin azaltılmasında son yıllarda hissedarlar aktif rol oynamaya başlamışlardır. Yatırımlarını korumak ve şirket değerini yükseltmek için hissedarlar bireysel ve kurumsal olarak etkinlikte bulunmaktadırlar. Geçmişte çevrenin korunması gibi sosyal amaçlı etkinlikler düzenlenirken günümüzde genel müdürün değiştirilmesi, yönetim başkanı ve genel müdürün farklı kişilerden oluşması, yönetim kuruluna kendi adaylarının üye seçilmesi, şirket alımı veya satımı, kâr dağıtımı gibi konularda faaliyetler yürütülmektedir. Türkiye’deki hissedar aktivizmi şirket sahipliğinin büyük ölçüde aile ve bireysel kişilerden oluşması, yatırım fonlarının ABD'deki gibi saldırgan davranmaması gerekçelerinden dolayı sınırlıdır. Büyük şirketlerin hisselerini yabancı ortaklara satması, uluslararası yatırım fonlarının risk iştahı, uygulamaya başlanan elektronik genel kurul sistemi ile hissedar aktivizmi yaşanmaya başlamıştır. Türkiye’nin ABD menkul kıymetler borsasına kote olan tek şirketi olan Turkcell'de hissedar etkinliğine tanık olunmaktadır. Bu çalışmada, hisseleri halka açık olan Turkcell ile Telekom şirketlerinin finansal durumu, genel kurullarında yönetim tarafından sunulan önerilerin kabul oranı ve hisse senedi fiyatlarının davranışı incelenmiştir. Telekom şirketinde hissedar aktivizmi görülmezken Turkcell şirketinde mahkemeye varan bir çekişme yaşanmış ve hissedarların korunması amacıyla yönetmeliklerde değişikliğe kadar gidilmiştir. Temel veriler incelendiğinde, Türk Telekom şirketinin faaliyet kârlllı̆̆ ve cari oranı Turkcell şirketine göre düşüktür. Yapılan çalışmada, telekomünikasyon sektöründe halka açık bu iki şirketin genel kurullarında yaşanan farklı hissedar aktivizminin hisse senedi fiyatları üzerinde anlamlı bir değişikliğe neden olmadiğı sonucuna varılmıştır. Her iki hisse senedi birbiri ile yüksek korelasyon içinde hareket etmektedir. Genel kurulları izleyen günlerde de piyasa fiyatlarında bir farklılaşma yaşanmamaktadır. Bu durumun nedenleri arasında, sektördeki büyümenin ulusal ekonominin üzerinde olması ve hissedarlar tarafindan alınan kararların şirketin geleceğine olumlu etki edeceğine yönelik yatırımcıların beklentileri sayılabilir.
\end{abstract}

Anahtar Kelimeler: Hissedar Aktivizmi, Temsil Kuramı, Telekomünikasyon, Türkiye

JEL Sınıflaması: G34, M12, M14

\section{Introduction}

Besides the technological changes, global uncertainties, increasing competition, low growth rates, which put pressure on the top management to achieve the firm goals, shareholders became dynamic actors to influence the board of directors. One naive rationale is the economic crises, which cause the bankruptcy of the firms, where shareholders lose their investments. Shareholders wish to track the operations of the firm and to intervene in the affairs of management whenever shareholders feel insecure about their capital. Another motivation is 
the short-term profit orientation of corporate shareholders whose long-term strategies may differ from the ones of the invested company.

Capital board regulators introduce mechanism to allow shareholders to take active part in the general meetings. Once called as fat cats ${ }^{1}$, executives face more challenges than ever to keep their positions under the critics and interventions of active shareholders. Global CEOs leaving their positions reached a high ratio of $17 \%$ in $2015.41 \%$ of the shareholder proposals given in 2015 during the general meeting aimed to separate the company's chairman and CEO positions ${ }^{2}$. Publicly owned companies which were subject to shareholder activism have increased by $46 \%$ from 2013 to 2016 globally ${ }^{3}$. While the USD 173 billion assets are managed by funds with a primary focus on activist investing, USD 250 billion stocks are held by activists worldwide at the beginning of the year $2016^{4}$.

The agency problem in finance literature is often seen as a problem caused by the management of the company who can be in conflict with the interests of the shareholders. In recent decades, shareholders have gained power through the corporate investment opportunities. Shareholders may act by taking into consideration short-term concerns which may be against the company's long-term strategies. These circumstances are often seen in the case of powerful shareholders, and investors who organize themselves in hedge funds. Driven by the short-term profit realization, shareholders vote against the recommendations of the board of directors.

Voting against the board of directors' recommendations affects the value of the shares of the company. The uncertainties about the future of the company, disharmony between the board of directors and shareholders, threats of the current and potential investors give chaotic signals to markets.

This paper is organized as follows: The second part explores the term of shareholder activism in the literature. The third part analyzes the activism in telecommunication sector in Turkey. There are two companies, namely Telekom and Turkcell, whose shares are publicly traded. These two companies are classified in the top fifteen biggest companies in Turkey. The forth part summarizes the findings of the research. The fifth and last part concludes and gives recommendations about future studies. This article contributes to the literature in many ways. First, it describes the shareholder activism in Turkey where there are few academic studies. Secondly, it investigates two companies operating in the same sector with completely contradictory activism movements. Finally, the relationship between the general meeting activism and firm values are compared.

1 Ergin, Emre, "Does Excessive Executive Compensation Really Pay Shareholders?", Academy of Accounting and Financial Studies Journal, 17 (1), 2013, ss. 47-51.

2 Copland, James R., The Push for Proxy Access Continues, Proxy Monitor Report, Manhattan Institute, 2016.

3 Black, Josh, The Activist Investing Annual Review 2017, Harvard Law School Forum on Corporate Governance and Financial Regulation, Feb. 21, 2017.

4 Black, Josh, Activist Investing, 2016. 


\section{Shareholder Activism Literature}

The term activism originates in the beginning of the 1900s to denote people who act vigorously in political issues. The degree of activism depends on how much people feel threatened. People who show activism are called activists. Activists usually take part in mass demonstrations, manifestations, strikes, boycotts and protests. The term has evolved to include other fields other than politics. Environmental activists act in a manner to protect the natural environment. Human right activists try to protect and enrich the fundamental rights and freedoms. Consumer activists act by their economic purchasing power to change the company operations for the goods or services produced. Media activism usually uses social media (facebook, twitter, instagram) to give news not broadcasted by traditional media (national television channel). Internet activism helps activists communicate with encrypted mails and chat rooms by hiding their identities. Youth activism refers to young people who protest against war, crime, education, unemployment, tax and other issues. Activist movements are spread in many different fields including political, social and economic issues to improve the world.

Shareholders reactions against the firm managements have taken different concepts in the literature other than activism such as engagement, advocacy and pressure ${ }^{5}$. Shareholder activism differs from the investor activism in the sense that the latter one tries to own a high percentage of firm's shares in order to control the board of directors to realize crucial changes in the management.

Shareholder activism is first started as an act either to promote social changes such as environmental and work conditions, or to influence management to act in the will of shareholders. Besides these social proposals, shareholders have also proposals related to corporate governance. Corporate governance issues may include the appointment of the audit company, release of restricted stocks and executive compensation. Shareholders try to make changes in the context of social responsibility or firm performance. Chung and Talaulicar ${ }^{6}$ state that shareholder actions are motivated either by social ends or by financial ends.

Although shareholders have the power to change the board of directors, it is not always possible to do that due to high or low ratio of publicly held companies and powerful board of directors. Thus, shareholders' power is limited to electing and removing management. Shareholders have to vote for capital issues such as capital increase and dividend payments, mergers and acquisitions which are indeed an outcome of the operations of the management.

Since the Great Depression, laws and regulations have been towards the protection of shareholders. The problem of the agency, that is the management, is tried to be reduced by implementing

$5 \quad$ Sjöström, Emma, "Shareholder Activism for Corporate Social Responsibility: What Do We Know?", Sustainable Development, 16 (3), 2008, s. 142.

6 Chung, Huimin and Talaulicar, Till, "Forms and effects of shareholder activism", Corporate Governance: An International Review, 18 (4), 2010, s. 253. 
mechanism allowing shareholders to monitor the management. U.S. Securities and Exchange Commission (SEC) introduced Rule $14 \mathrm{a}-8$ to allow shareholders to submit proposals to the annual general meeting. Black 7investigated the activism in the firm's financial performance and defined the term as the proactive efforts to change firm behavior in economic goals. $\mathrm{He}$ concluded that activists' efforts are low and even when their proposals are accepted in the general meeting, the management is reluctant to implement them. Low ${ }^{8}$ defines shareholder activism as the minority shareholders who use their rights to increase shareholder value over the long term. However, activism is neither unique to minorities nor is practiced for long run purposes. Sjöström ${ }^{9}$ defines the concept as shareholders who use their position to influence firm policy and practice. Armour and Cheffins ${ }^{10}$ distinguish between defensive and offensive activism. The former one is a reaction of corporate shareholders, such as mutual funds and pension funds, in order to make changes in the company when they are not satisfied with the consequences. Offensive activism is a proactive behavior by hedge funds which try to make changes in the company before the outcomes are obtained. Shareholder activism which demonstrates itself by hedge funds in the US affected corporate governance after the 2000s. Brav et al. ${ }^{11}$ show the activist hedge funds generally success to influence corporate governance through CEO and to increase dividend payments. Not only the activities of current shareholders, but also the potential threat of future activists has a corrective effect on management behavior ${ }^{12}$. Activists can contribute to the firm value by their creative ideas which are later discussed by the management which usually prefers to deal with ideas concerning long-term strategies. Cohn et al. ${ }^{13}$ give evidence that increased shareholder control helps contribute to the firm value maximization in favor of shareholders for the large and medium sized firms. However, the success rate of shareholders' demands is approximately $65 \%$ for the US and the UK, and almost $50 \%$ for the Asia region ${ }^{14}$. The statistics shows that management paysmore attention to shareholders' demands than it used to be. This allows shareholders to decrease agency costs. To give a few examples, when unsatisfactory shareholders of Walt Disney forced management to restructure the company, the $\mathrm{CEO}$ and general manager Eisner lost some of his authorities. Apple faced a court case from a corporate shareholder, Greenlight Capital Inc., to distribute more dividends. Another hedge fund, Third Point LLC, put pressure on Yahoo to have a word in the management of the company.

Black, Bernard S., 1998. Shareholder activism and corporate governance in the United States. In: Newman, Peter (Ed.), The New Palgrave Dictionary of Economics and the Law, 3, 1998, s. 460. 
Other well-known companies like Microsoft, eBay and PepsiCo faced active investors. Statistics shows that shareholder proposals are increasing: Proposals in 2016 increased by 7,5\% compared to those in 2015 and by $48 \%$ compared to those in 2014 in the USA. One third of the proposals come from retirement funds, another one third from powerful individual shareholders, and $22 \%$ from the context of social responsibilities. Approximately $43 \%$ of proposals are for corporate governance, $42 \%$ are for social policy, and $15 \%$ are for executive compensation ${ }^{15}$.

Activists try to replace board members, make a part or the whole of the firm sell, go into mergers and acquisitions. Activists movements contribute to the firm value by involving management in taking more initiatives, asking management to consider other opportunities, using idle sources more effectively (either by distributing them as dividends or by investing), and giving a signal to top management team to behave in the benefit of the shareholders. On the other hand, the main criticism against the activist shareholders is that they are short-term oriented which may disturb the long-term strategic plans of the firm. The mismanagement of the communication between management and shareholders leads shareholders to act in such a way that management gives their energy on this debate instead of concentrating on main business activities. The outcome is the worsening of the financial statements and market price which makes shareholders to take even more severe measures.

Continental European and Anglo-Saxon models exist in the context of corporate governance. The models distinguish from one to another in terms of culture, jurisdiction and market behaviors. Ownership concentration is high in the European model so that the focus is on the stakeholders such as employees, suppliers and banks. Families own companies in Germany, France and Japan so the minority rights are reinforced by laws such as executive compensation voting. The latter one which is represented by the USA, England, Canada and Australia focuses on shareholders where the ownership is dispersed through the stock market. The major investors are mutual funds which may behave in profit maximization concerns in the short-term. When the investors believe the company is not properly managed, they can turn to activist shareholders to change the management, make mergers or acquisitions, affect the dividend distribution, and make borrowings. The top management is afraid of these kinds of activist shareholders. On the other hand, the executive compensation which is usually linked to company profits and shares, forces top managers to achieve success in the short-run in risky plans neglecting long-term sustainable investments. This dilemma pushes shareholders to act as traders. These are the reasons why the activist movements are high in the Anglo-Saxon culture. A recent survey showed that there were 223 activists cases in the USA, while there were only 35 cases in Europe. The half of the target was board membership, and the rest were merger, acquisition, financial statements, management, and executive compensation. Ganchev ${ }^{16}$ found a $29 \%$ of success rate of activism over 504 campaigns

15 Copland, Ibid.

16 Gantchev, Nickolay, "The Costs of Shareholder Activism: Evidence from a Sequential Decision Model", Journal of Financial Economics, 107 (3), 2013, s. 625. 
analyzed. Most of the campaigns were organized to prevent the sale of the company to a third party. The other campaign subjects were dividends, repurchase and excess cash.

Activism can be analyzed in term of its costs. Proposals, negative votes and vote-no campaigns are low cost activist behaviors. These low cost strategies are important as it is difficult to own large shares even for the hedge funds which try to diversify their investments. Ertimur et al. ${ }^{17}$ provide evidence on a $38 \%$ decrease of CEO total pay caused by low cost activism. Shareholder activism may also be costly due to aggressive negotiations with management and organized campaigns. Independent financial consulting firms emerged in order to provide services to activist shareholders during their campaigns to overcome management actions that might not be the optimum strategy for shareholders. The service continues after the activists earn a member seat in the board. Thus, in situations where the costs of activism are high, the benefits taken by the shareholders might be limited. However, increasing and recent literature on shareholder activism promises a surplus for shareholders.

\section{Shareholder Activism In Turkey: Telecomunication Case}

Turkish corporate governance environment is similar to the European model as a result of the presence of companies owned largely by individuals or families, the low percentage of free float rate of publicly traded companies, and the integration process with the EU. 95\% of companies in Turkey are classified as small and medium sized enterprises, and owned by families. The disclosure of the executive compensation was discussed but omitted when the new Turkish Commercial Code came into effect in 2011. Shareholders now have the right to reveal their thoughts, ask questions, comment on financial statements, discuss the performance of the company, question board member candidates during the presentation of the résumé, and proxy voting.

Investment funds do not show activist movements in Turkey. The stock market and the instruments are quite new compared to those in the USA and Europe. Growing market and traditional investment strategies restrain activist behavior. However, Turkcell case is an important example of shareholders who pursue different strategies to take control over the company.

It is difficult for the activist shareholders to reach their goals when an important percentage of the Turkish companies is controlled by a family. However, the need to raise capital through stock market, legislations to strengthen minority rights, foreign investors owning two third of the Turkish stocks, growing corporate funds stimulated by the government, and the desire of the investors for more profits in the shortest period will help the activist shareholder mentality flourish in Turkey.

17 Ertimur, Yonca and Ferri, Fabrizio and Muslu, Volkan, "Shareholder Activism and CEO Pay", The Review of Financial Studies, 24 (2), 2011, s. 537. 


\section{I. Shareholder Activism In The General Board}

Shareholders activism can take several forms: refusing or abstaining from voting during the general board meeting; putting an annotation to the minutes of the board at the end of the meeting. In the extreme cases, shareholders also have the right to sue the decisions taken during the meeting.

In the general meetings, shareholders can refuse or abstain from the following decisions: electing the chairmanship committee, authorizing the chairmanship committee to sign the minutes, approving the balance sheet and profit/loss accounts for the year, releasing the board of directors, defining the salaries of the members of the board of directors, electing members of the board of auditors and defining their terms of office and their salaries, resolving on the proposal of the board of directors regarding the distribution of the profit, electing the independent auditor, determining limit donations and aids to be made, approving dividend policy and dividend payout ratio.

Shareholders in Turkey can ask questions in the general meetings organized electronically. This kind of meeting allows efficiency and effectiveness in terms of participation costs, time and security. Shareholders may share their ideas, ask online questions and get answers from the management. A study showed shareholders had 455 propositions and 420 negative votes during 2013 and 2014 electronic general meetings ${ }^{18}$. The opportunities of direct communication give shareholders to know each other and increase the understandings. The activism concerns topics such as executive compensation, donations, dividend policy, and representation of women. This new meeting style enforces transparency and accountability as well.

Ferri ${ }^{19}$ documents that delays in voting practices (for instance, triennial as opposed to annual) reduces management responsiveness to shareholders, hence reducing management accountability. Prevost et al. ${ }^{20}$ highlight the character of activist shareholders who try to communicate and cooperate with other influential shareholders so that the sharing of information decreases the uncertainties on stock prices that become more informative. Thus, frequent voting and electronic meetings where shareholders meet each other as well as management contribute positively to corporate governance.

18 Ergincan, Yakup and Karaağaçlı, Bora, "How Electronic General Meetings Affected Exercise of Shareholder Rights in Turkey: An Analysis of the Turkish Model in Light of International Market Standards and Regulations”, Boğaziçi Journal Review of Social, Economic and Administrative Studies, 29 (1), 2015, s. 113.

19 Ferri, Fabrizio and Oesch, David, "Management Influence on Investors: Evidence from Shareholder Votes on the Frequency of Say on Pay”, Contemporary Accounting Research, 33 (4), 2016, s. 1362.

20 Prevost, Andrew K. and Wongchoti, Udomsak and Marshall, Ben R., "Does institutional shareholder activism stimulate corporate information flow?", Journal of Banking and Finance, 70, 2016, s. 115. 


\subsection{Telecommunication Industry}

The demographic characteristics of the Turkish population which reveal itself in its large size, youth, urbanization, and interest in high technology services like the upcoming 5G promise growth and profitability in the telecommunication market. This is the main reason why foreign investors are interested in the Turkish market. All of the four big companies have foreign shareholders.

The major players in the Turkish telecommunication market are Türk Telekom Group, Turkcell, Vodafone and Avea. The first company mentioned above is the main fixed line operator. The three others are the main mobile operators. Shareholder structure of Türk Telekom and Turkcell are given in Table 3.1.

Table 3.I: Shareholder Structure (Thousand TL)

\begin{tabular}{lcc}
\hline Shareholders & $\%$ & Nominal Shares \\
\hline Ojer Telekomünikasyon A.Ş. & 55,00 & 1.925 .000 \\
Turkish Treasury & 30,00 & 1.050 .000 \\
Publicly traded shares & 15,00 & 525.000 \\
\hline Total Türk Telekom & $\mathbf{1 0 0 . 0 0}$ & $\mathbf{3 . 5 0 0 . 0 0 0}$ \\
& & \\
Turkcell Holding A.Ş. & 51,00 & 1.122 .000 \\
Publicly traded shares & 48,95 & 1.077 .004 \\
Others & 0,05 & 996 \\
\hline Total Turkcell & $\mathbf{1 0 0 , 0 0}$ & $\mathbf{2 . 2 0 0 . 0 0 0}$ \\
\hline
\end{tabular}

The origin of Türk Telekom can be traced back to the foundation of a state company in 1840 . The initial name and services changed several times until the privatization in 2005 when 55\% of the shares were sold to Ojer Telekomünikasyon A.Ş. (“OTAŞ”). Turkish treasury offered 15\% of the shares to stock market. Türk Telekom dominates the market by its fixed line operators and infrastructure in the country. It also started fiber network technology investment.

Turkcell is the leader in terms of total revenues in the market. Turkcell is the only Turkish stock listed in another stock market, namely The New York Stock Exchange. Although four consecutive Turkcell general meetings after 2011 were held, they were cancelled due to disagreement. On 26 March 2015 the general meeting for the periods from 2010 to 2014 was held. In fact, the conflicts among the three big shareholders of Turkcell -Turkish Çukurova Group, Baltic TeliaSonera and Russian Alfa- began ten years ago. Due to the economic problems of Çukurova Group who was also operating in the banking sector, shares were exchanged and also put in pledge between these companies which ended in lawsuits for the ownership of the shares during 2005 and 2010. The unresolved disputes pushed TeliaSonera and Alfa to block the general meetings during the years 
2010 and 2014 in order to prevent Çukurova Holding from having loan opportunities and being forced to accept their proposals. The total distributable dividends reached TL 4 billion. In 2013, the Capital Markets Board of Turkey (CMB) published a bulletin affirming that they can appoint independent board members to companies whose general meeting is not held for two consecutive periods to protect minorities' rights. This minute was perceived positively and the shares increased by $1 \%$ in the markets. In March 2013 the CMB appointed three independent members to the board. However, shareholders could not agree again and the previous board member election period was completed and the new ones could not be appointed. Thus, members from the CMB were left alone in the board. The Turkish Parliament passed a new law to permit the CMB to appoint more independent members to companies. Towards the end of 2014 and at the beginning of 2015 important managers, including the chief executive officer leading the company since 2007, left. At the 26 March 2015 general meeting, fiscal years from 2010 to 2014 were approved, the board members were released, profit distribution policy, and profit distribution were accepted; while the main agreement amendment was not accepted. However, main agreement amendment, share repurchase authority to board of directors and profit distribution were not accepted in the general meeting of 2015 held on 29.03.2016.

\section{Research}

\section{I. Fundamental Analysis}

The selected figures from the financial statements of both firms for the years 2016 and 2015 are shown in Table 4.1 .

Türk Telekom has a weak current ratio $(1,11)$, high long-term bank borrowings, and low shareholders' equity due to the loss occurred and the distribution of profits in the previous years. The company's 2016 loss comes majorly from the foreign currency expenses as result of the high devaluation of Turkish Lira. Turkcell has an adequate current ratio $(1,81)$, a balanced asset and liabilities, and high shareholder' equity because of undistributed dividends. As of 31.12.2016, the cumulative profit reached almost TL 13 billion. Sales growth exceeds 10\% in both companies; operating profit (EBIT) has decreased as compared to the prior year, and is $13 \%$ and $24 \%$ for Türk Telekom and Turkcell respectively. Türk Telekom generates cash from operations higher than its competitor. Turkcell has a greater market share price which makes its market to book ratio lower, having a greater market capitalization.

Although Turkcell has approximately $10 \%$ less sales than the market leader, it has strong financial figures except the cash obtained from operations, which is not a drawback. Turkish treasury still owning 30\% of Telekom gives an additional confidence to Türk Telekom investors apart from its growing and giant aspects. 
Table 4.I: Brief Financial Data (Million TL)

\begin{tabular}{|c|c|c|c|c|}
\hline & \multicolumn{2}{|c|}{ Türk Telekom } & \multicolumn{2}{|c|}{ Turkcell } \\
\hline & 31.12 .2016 & 31.12 .2015 & 31.12 .2016 & 31.12 .2015 \\
\hline Current Assets & 9.236 & 8.442 & 13.351 & 8.795 \\
\hline Fixed Assets & 17.639 & 17.332 & 18.249 & 17.389 \\
\hline Total Assets & 26.874 & 25.774 & 31.600 & 26.184 \\
\hline Short Term Liab. & 8.352 & 8.553 & 7.359 & 6.304 \\
\hline Long Term Liab. & 15.136 & 12.228 & 8.173 & 5.481 \\
\hline Shareholders' Equity & 3.387 & 4.993 & 16.068 & 14.399 \\
\hline Sales & 16.109 & 14.523 & 14.101 & 12.769 \\
\hline Gross Profit & 7.130 & 6.957 & 5.067 & 5.003 \\
\hline EBIT & 2.140 & 3.039 & 3.451 & 3.341 \\
\hline Financial Exp. Net & -2.593 & -1.904 & -1.383 & -1.135 \\
\hline Profit Before Tax & -397 & 1.261 & 1.563 & 2.206 \\
\hline EPS (TL) & $-0,207$ & 0,259 & 0,689 & 0,941 \\
\hline $\mathrm{CF}$ from Operations & 4.932 & 4.498 & 1.218 & 2.663 \\
\hline CF from Investing & -4.612 & -3.166 & -3.588 & -4.324 \\
\hline CF from Financing & -402 & -1.156 & 4.839 & -4.887 \\
\hline Market to Book Ratio & 5,46 & 3,68 & 1,33 & 1,51 \\
\hline Price/(EBIT/Capital) & 8,65 & 6,29 & 6,20 & 6,52 \\
\hline Capital & 3.500 & 3.500 & 2.200 & 2.200 \\
\hline Market Share Price & 5,29 & 5,46 & 9,73 & 9,90 \\
\hline Market Capitalization & 18.515 & 19.110 & 21.406 & 21.780 \\
\hline
\end{tabular}

Note: Sums may not be correct due to rounding. EPS stands for earnings per share. CF stands for cash flow.

\subsection{Shareholder Activism in General Meetings}

Shareholders of Turkcell try to control the management so that the general meetings could not be performed for four consecutive years in the past. Therefore, in 2015, the general meeting was conducted concerning five years (from 2010 to 2014). Although each year's agenda was discussed and voted separately, the votes were in the same pattern for each year. Table 4.2 reports the acceptance percentage of the selected agenda topics of the 2016 and 2015 general meeting voting of Türk Telekom and Turkcell for the fiscal years of 2015 and 2014. As it can be noticed, there is almost a perfect harmony in the decisions taken by the shareholders of Türk Telekom, and none of the proposals were rejected. On the other hand, in the general meeting of Turkcell, not even one decision was unanimous, and some rejected. There were even some contradictory decisions taken in Turkcell; for instance, dividend policy was accepted but dividend distribution was rejected. According to Table 4.2, in 2015 one management proposal and in 2016 three were rejected. The agenda concerning donation limit in 2016 was accepted by a low percentage of $64 \%$. 
Table 4.2: Percentage (\%) of Acceptance in the General Meeting

\begin{tabular}{|l|r|r|r|r|}
\hline & \multicolumn{2}{|c|}{ Türk Telekom } & \multicolumn{2}{c|}{ Turkcell } \\
\hline Agenda|Dates & $\mathbf{1 6 . 0 5 . 2 0 1 6}$ & $\mathbf{3 1 . 0 3 . 2 0 1 5}$ & $\mathbf{2 9 . 0 3 . 2 0 1 6}$ & $\mathbf{2 6 . 0 5 . 2 0 1 5}$ \\
\hline Election of chairman & 100 & 100 & 99,999 & 99,933 \\
\hline $\begin{array}{l}\text { The reading of the summary of the } \\
\text { annual report }\end{array}$ & 98,014 & 97,427 & 94,878 & N/A \\
\hline Approval of the financial statements & 99,998 & 100 & 99,954 & 99,889 \\
\hline Release of the board members & 99,997 & 99,998 & 99,822 & 98,348 \\
\hline Donation policy & N/A & N/A & 99,886 & 98,364 \\
\hline $\begin{array}{l}\text { Following year's donation upper limit } \\
\text { determination }\end{array}$ & N/A & N/A & 64,106 & 98,364 \\
\hline Main agreement change & N/A & N/A & 27,134 (R) & 23,967 (R) \\
\hline Auditor selection & 99,529 & 99,597 & 99,221 & 98,494 \\
\hline Share repurchase authorization & N/A & N/A & 27,331 (R) & N/A \\
\hline Dividend distribution & 100 & 100 & 42,028 (R) & 99,242 \\
\hline
\end{tabular}

Note: This table presents the acceptance percentage of the selected topics during the general meetings. The agenda does not include all the topics discussed in the meeting. (R) stands for the proposal which is rejected. $\left(^{*}\right)$ shows dates of the general meeting; for instance, 2016 is the general meeting for the 2015 fiscal year. N/A stands for not applicable meaning that either the topic was not included in the agenda or there was no voting.

In the following part, the effects of these rejections are analyzed.

\subsection{Share Price Behavior}

The descriptive statistics are presented in the Table 4.3 for the period from 01.01.2014 to 31.12.2016.

Graphic 4.1 shows the share price movements over a three-year period (01.01.2014-31.12.2016) where Turkcell is set to the same starting point of Türk Telekom to analyze the correlation between them. Both shares move in very similar ways to each other and at the end of the three-year period they are very close. There is an upper movement which starts at the beginning of the years (before general meetings) for 2014, 2015 and 2016, and followed by a decrease towards the summer (after the general meetings) for the 2015 and 2016 years. Even though Türk Telekom paid dividends and Turkcell did not in 2016, the trends of both shares were quite similar. Shareholder activism in the general meetings has no effect in the long-run of share prices. 
Table 4.3: Descriptive Statistics

\begin{tabular}{lccr}
\hline & Türk Telekom & Turkcell & BIST 100 \\
\hline Mean & 5,83 & 10,98 & $77.681,57$ \\
Standard Error & 0,02 & 0,03 & 208,81 \\
Median & 5,80 & 10,98 & $78.019,48$ \\
Standard Deviation & 0,54 & 0,94 & $5.737,53$ \\
Kurtosis & $-0,96$ & $-0,87$ & 0,51 \\
Skewness & 0,08 & 0,05 & $-0,59$ \\
Range & 2,37 & 4,65 & $30.223,79$ \\
Maximum & 7,04 & 13,54 & $91.412,94$ \\
Minimum & 4,68 & 8,89 & $61.189,15$ \\
Confidence Level (95\%) & 0,04 & 0,07 & 409,92 \\
\hline N: 755. BIST 100 index is a capitalization-weighted index composed of 100 national market companies.
\end{tabular}

Graphic 4.I: Türk Telekom and Turkcell Share Prices

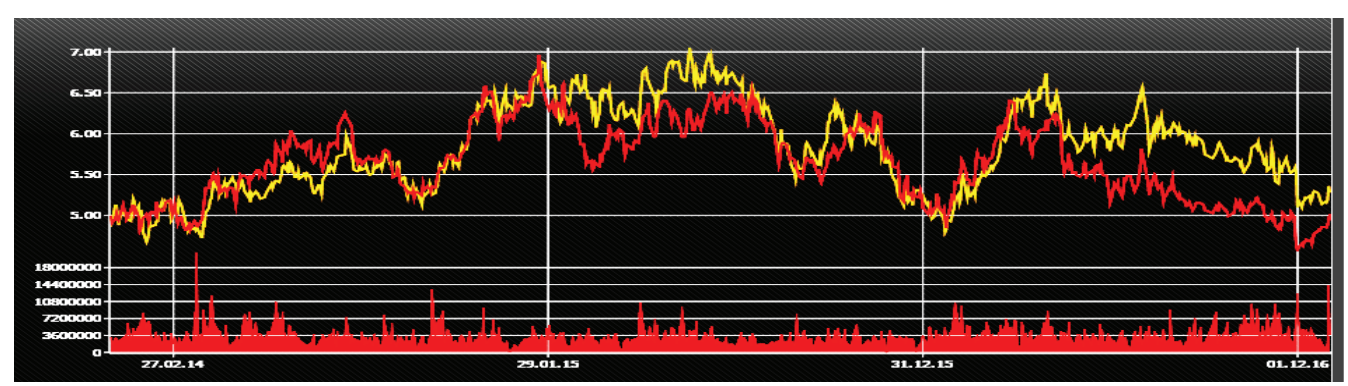

Source: www.finans.mynet.com. Türk Telekom (yellow line) and Turkcell (red line) share price movements for the period of 01.01.2014 and 31.12.2016. The shares are set to the same starting point in the graphic to notice the correlation.

Another investigation made is whether the share prices reacted to the general meetings decisions to see the short-term effect. The share prices are obtained for the ten days following the general meeting. The share price changes and the correlations are analyzed up to ten days in a cumulative way to observe whether the data from the general meetings are fully obtained by the market. From the percentage changes in share prices, the percentage change in the whole market index (XU 100 or BIST 100) is eliminated to obtain the real changes of the observed shares. There has been found not significant correlation. It is concluded that the share prices are not affected by the shareholder activism in the short or long term. Table 4.4 presents the correlation matrix.

Table 4.4: Correlation Between Variables

\begin{tabular}{lcc}
\hline Variables & Turkcell & BIST-100 \\
\hline Türk Telekom & $0,784^{*}$ & $0,823^{\star}$ \\
Turkcell & & $0,767^{*}$ \\
\hline
\end{tabular}

Notes. $\mathrm{n}=755 .^{\star}$ : significant at the $p<.001$. 
There is a significant very strong positive relationship among all the variables. Further analysis is conducted by using event study methodology. Event dates are the four general meetings dates shown in Table 4.2. Expected returns, abnormal returns (AR), cumulative abnormal returns (CAR), and t-statistics are calculated for the hundred days before the event dates and 10 days following the event dates. The $\mathrm{t}$-statistics being greater than 1.96 for the 10 days after the event dates are considered as significant. However the single-factor model does not give assurance whether the ARs and CARs are the solely result of the general meetings. Therefore a two-factor model is constructed by using BIST 100 to investigate if the stocks ARs are the results of the general meetings or the behavior of the stocks are in line with the market behavior. It is found that a few days have significant t-statistics, meaning that the investors take into consideration the results of the general meetings, but these days are followed immediately by opposite returns to off-set the significant ARs and CARs. It is concluded that shareholder activism has not significant effect on the share prices.

\section{Conclusion}

The firms face shareholder activism for many reasons. The general stimulus of shareholders is the poor financial performance of large firms which is indicated by either low sales, earnings, dividend payment policies or market values. Another stimulus is usually driven by corporate shareholders, namely hedge funds which target small firms by aiming various strategies usually focusing on short-term returns. The general outcome of shareholder activism has a positive influence on firm value and corporate governance as compared to years before the $2000 \mathrm{~s}^{21}$. The shareholder structure, cultural mind-set and company size are important criteria for activism.

Shareholder activism is especially witnessed in the Anglo-Saxon countries followed by the European countries. However, there is a sharp increase in other part of the world such as Japan. Turkey, being similar to European corporate structure in terms of ownership structure, has a low percentage of shareholder activism. This trend changes with the international funds investing in the country and increasing shareholder rights such as the electronic general meeting system introduced lately. This paper examined Turkish telecommunication sector where the two big companies' shares are traded publicly. One company does not witness any shareholder activism, whereas the other strongly faces activism. However, the shareholder activism does not seem to affect share prices in the period just after the general meetings, or also in the long-term period. Reasons might be the double digit growth potential of the sector and investors' trust in these two big companies.

Research shows shareholder activism contributes to the firm value by decreasing agency costs. New mechanism should be adapted to increase shareholder communication. One alternative may be the proposals given by shareholders in the USA. In Turkey, proposals are made during the general

21 Denes, Matthew R. and Karpoff, Jonathan M. and McWilliams, Victoria B., "Thirty years of shareholder activism: A survey of empirical research”, Journal of Corporate Finance, in press, 2017. 
meetings. However, shareholders may submit their proposals before the general meeting. The proposal, the answer and recommendation of the management might be published in the annual report before the general meeting to allow parties to examine the proposals. This shareholder right can be implemented in Turkey in the future to allow shareholders to communicate their ideas and to get support before the meetings. Further research can be carried out to examine the shareholder activism in other sectors, and its relationship to market value.

\section{References}

Activist Insight, Activist Investing Review, 2016, s. 9-10.

ARMOUR, John and Cheffins, Brian, “The Rise and Fall (?) of Shareholder Activism by Hedge Funds”, Journal of Alternative Investments, 14 (3), 2012, s. 17-27.

BLACK, Josh, Activist Investing 2016, www.activistinsight.com

BLACK, Josh, The Activist Investing Annual Review 2017, Harvard Law School Forum on Corporate Governance and Financial Regulation, Feb. 21, 2017.

BLACK, Bernard S., "Shareholder activism and corporate governance in the United States", In: Newman, Peter (Ed.), The New Palgrave Dictionary of Economics and the Law, 3, 1998, s. 459-465.

BRAV, Alon and Jiang, Wei and Kim, Hyunseob, "Hedge Fund Activism: A Review. Foundations and Trends in Finance", 4 (3), 2009, s. 185-246.

CHUNG, Huimin and Talaulicar, Till, "Forms and effects of shareholder activism”, Corporate Governance: An International Review, 18 (4), 2010, s. 253-257.

COHN, Jonathan B. and Gillan, Stuart L. and Hartzell, Jay C., "On Enhancing Shareholder Control: A (Dodd-) Frank Assessment of Proxy Access, The Journal of Finance, 71 (4), 2016, s. 1623-1668.

COPLAND, James R., The Push for Proxy Access Continues, Proxy Monitor Report, Manhattan Institute, 2016.

DENES, Matthew R. and Karpoff, Jonathan M. and McWilliams, Victoria B., "Thirty years of shareholder activism: A survey of empirical research", Journal of Corporate Finance, in press, 2017.

ERGIN, Emre, "Does Excessive Executive Compensation Really Pay Shareholders?", Academy of Accounting and Financial Studies Journal, 17 (1), 2013, s. 47-56.

ERGİNCAN, Yakup and Karaağaçlı, Bora, "How Electronic General Meetings Affected Exercise of Shareholder Rights in Turkey: An Analysis of the Turkish Model in Light of International Market Standards and Regulations", Boğaziçi Journal Review of Social, Economic and Administrative Studies, 29 (1), 2015, s. 95-117.

ERTIMUR, Yonca and Ferri, Fabrizio and Muslu, Volkan, "Shareholder Activism and CEO Pay", The Review of Financial Studies, 24 (2), 2011, s. 535-592.

FERRI, Fabrizio and Oesch, David, "Management Influence on Investors: Evidence from Shareholder Votes on the Frequency of Say on Pay", Contemporary Accounting Research, 33 (4), 2016, s. 1337 1374.

FOS, Vyecheslav, The Disciplinary Effects of Proxy Contests, Working paper, Columbia University, 2011.

GANTCHEV, Nickolay, "The Costs of Shareholder Activism: Evidence from a Sequential Decision Model", Journal of Financial Economics, 107 (3), 2013, s. 610-631.

LOW, Chee K., "A Road Map for Corporate Governance in East Asia", Northwestern Journal of International Business Law, 25, 2004, s. 165-203. 
PREVOST, Andrew K. and Wongchoti, Udomsak and Marshall, Ben R., "Does institutional shareholder activism stimulate corporate information flow?", Journal of Banking and Finance, 70, 2016, s. 105-117.

SJÖSTRÖM, Emma, "Shareholder Activism for Corporate Social Responsibility: What Do We Know?", Sustainable Development, 16 (3), 2008, s. 141-154. 